\title{
Regulation of Immunocompetence by Different Androgen Metabolites in a Blenny with Alternative Reproductive Tactics
}

\author{
ALBERT FRANK HUASCAR ROS ${ }^{1 *}$, CATARINA FERREIRA ${ }^{2}$, \\ RICARDO SERRÃO SANTOS ${ }^{2}$, AND RUI FILIPE OLIVEIRA ${ }^{1}$ \\ ${ }^{1}$ Instituto Superior de Psicologia Aplicada, Unidade em Eco-Etologia, \\ 1149-041 Lisbon, Portugal \\ ${ }^{2}$ Departamento de Oceanografia e Pescas, Universidade dos Açores, \\ Horta, 9901-862 Horta, Portugal
}

\begin{abstract}
In Parablennius parvicornis, small reproductive males with relatively low expression of secondary sexual characters (M- morphotype) parasite on the parental investment of the larger nest-holder males which have fully developed secondary sexual characters ( $\mathrm{M}+$ morphotype). In comparison with $\mathrm{M}+$ males, $\mathrm{M}-$ males have relatively low levels of androgens while having high blood cell percentages of lymphocytes and antigen responsiveness. Here we test the hypothesis that androgens are a causal factor for these differences in immunocompetence between morphotypes. After drawing an initial blood sample, males received a silastic implant containing either oil only (C), or oil with testosterone (T) or 11-ketotestosterone (KT). Males were re-caught 2 weeks later for drawing of the final blood sample. KT but not T induced the development of secondary sexual characters in M- males. M- males treated with KT showed lower swimming activity than the males treated with $\mathrm{T}$ or $\mathrm{C}$ implants, suggesting that $\mathrm{KT}$ also mediates behavioral changes in M- males. As expected, blood cell percentages of lymphocytes, but not of granulocytes, were higher in $\mathrm{M}-$ males than in $\mathrm{M}+$ males. Overall, lymphocyte percentages increased in the $\mathrm{C}$ group which might have been a response to the surgery/treatment. In concordance with the hypothesis, lymphocyte percentages were suppressed in males treated with $\mathrm{T}$ in comparison with controls. However, no significant change was found in KT-treated males. This suggests that androgens modulate central, morphological and immunological traits by partly independent androgen mechanisms in P. parvicornis. J. Exp. Zool. 305A:986-994, 2006. (c) 2006 Wiley-Liss, Inc.
\end{abstract}

How to cite this article: Ros AFH, Ferreira C, Santos RS, Oliveira RF. 2006. Regulation of immunocompetence by different androgen metabolites in a blenny with alternative reproductive tactics. J. Exp. Zool. 305A:986-994.

Success in sexual competition between individuals is strongly determined by displaying exaggerated sexual traits that are expected to be costly (Kotiaho, 2001) and this might generate a tradeoff between those mechanisms optimizing reproduction and those optimizing survival (Sheldon and Verhulst, '96; Deerenberg et al., '97; Norris and Evans, 2000; Cichoñ et al., 2001). In order to understand the proximate mechanism of such a trade-off, Folstad and Karter ('92) suggested studying the regulation of immunocompetence by sex steroids that reliably signal the individual's readiness to reproduce. Wedekind and Folstad ('94) proposed that suppression of the immune system by androgens would be adaptive since this would optimize the allocation of resources towards sexual traits necessary for successful reproduction. If so, displaying exaggerated androgen-dependent traits should compete for resources with the immune system (Schmid-Hempel, 2003; Demas, 2004) and be costly in terms of a loss of protection against pathogens. Therefore, Folstad and Karter ('92) postulated that such traits would reveal the quality of the male to resist

Grant sponsor: Portuguese Foundation for Science and Technology (FCT); Grant number: SFRH/BPD/7143/2001.

${ }^{*}$ Correspondence to: A.F.H. Ros, Instituto Superior de Psicologia Aplicada, Unidade em Eco-Etologia, Rua Jardim do Tabaco 34, 1149041 Lisbon, Portugal. E-mail: aros@ispa.pt

Received 10 July 2006; Revised 24 August 2006; Accepted 13 September 2006

Published online 13 October 2006 in Wiley InterScience (www. interscience.wiley.com). DOI: $10.1002 /$ jez.a.349. 
parasites and coined this the "Immunocompetence Handicap".

Among teleost fish, the relationship between androgens, secondary sexual characters and immunity has been best studied in the rainbow trout (Oncorhynchus mykiss) and the Chinook, salmon (Oncorhynchus tsawytscha). When testes mature at the start of the reproductive season males of Oncorhynchus spp. grow the typical hooked nose or "kype", which later plays a role in sexual competition (Witten and Hall, 2002). A castration study in a related species (Oncorhynchus nerka Kennerlyi; Robertson, '61) showed that testes development is associated with a strong degeneration of immune tissue, and an increase in infections and mortality. Since mature testes are a major source of androgens (Manning and Kime, '85; Campbell et al., 2003), androgens were expected to orchestrate both the development of the secondary sexual characters and immunosuppression. In vivo and in vitro studies showed that both testosterone (T) and 11-ketotestosterone (KT) were able to suppress antigen production by leukocytes, and that $\mathrm{T}$ (KT has not been studied) stimulated apoptosis of these cells (Slater et al., '95a; Slater and Schreck, '97). Furthermore, androgen receptor activity was found in leukocytes of both species (Slater et al., '95b; Slater and Schreck, '98).

In teleost fish in general, it is not $\mathrm{T}$ but its nonaromatizable metabolite $\mathrm{KT}$ that has a permissive effect on the development of secondary sexual characters and on some male reproductive behaviors (Kindler et al., '91; Borg, '94; Oliveira, 2004, 2005; Ros et al., 2004). However, measures of immunocompetence have been found to be suppressed to a similar extend by both T and KT (Slater and Schreck, '93; Slater et al., '95a; Slater and Schreck, '97; Hou et al., '99; Law et al., 2001; Yamaguchi et al., 2001; Watanuki et al., 2002; Saha et al., 2003). Moreover, receptor activity in the cytosol seemed to be more specific for T, while $\mathrm{KT}$ and $\mathrm{T}$ bound with similar affinity to whole leukocytes (Slater et al., '95b; Slater and Schreck, '98). Our aim was to study whether the same androgen modulates both immunity and secondary sexual characters in a teleost fish species.

Male rock-pool blenny, Parablennius parvicornis (Vallenciennes, 1836; e.g., Zander, '79; Santos, '89) displays two distinct morphotypes expressing alternative reproductive tactics (Santos, '85; Santos and Almada, '88; Oliveira et al., 2001b). Males of the $\mathrm{M}+$ morphotype have fully developed secondary sexual characters (head-hump and pheromone producing anal glands) and compete for crevices in the rock of inter-tidal pools where they establish nests, attract females to spawn and care for the eggs. Males of the M- morphotype have undeveloped secondary sexual characters but have relatively larger testes (Santos, '95). Generally, males first express the M- morphotype and switch to the $\mathrm{M}+$ morphotype during the second or third year and this is correlated with an increase in androgens, in particular KT (Oliveira et al., 2001c,d; Ros et al., 2006). It is worth mentioning that behavioral changes precede the morphotype switch and are primarily correlated with neurochemical changes (Miranda et al., 2003), although they are facilitated by androgens later on in the reproductive context (Ros et al., 2004; but see Oliveira et al., 2001c,d). As expected from the hypothesis that androgens are immunosuppressive, we have shown in a previous study that males of the $\mathrm{M}+$ morphotype had relatively less lymphocytes and lower antibody responses than M- males (Ros et al., 2006). However, these measurements of humoral immunocompetence did not show a negative correlation with circulating levels of $\mathrm{T}$ and $\mathrm{KT}$ questioning the causality of the pattern found.

Males may differ in their ability of coping with pathogens due to variation in individual condition, which may mask the immunosuppressive effect of androgens (e.g., Peters, 2000). A critical test of the immunocompetence handicap therefore requires the manipulation of androgen levels (Roberts et al., 2004). Therefore, in this study we analyzed the effect of androgen treatment ( $\mathrm{T}$ and $\mathrm{KT}$ ) on immunocompetence in an Azorean population of $P$. parvicornis. We selected lymphocyte counts as an indicator of immunocompetence. Although the validity of this monitoring method has risen some doubts as to whether high levels of lymphocytes map high immunocompetence or high infection status (Norris and Evans, 2000), possible changes in these levels would reveal an effect of the treatment on immunity (Nava et al., 2001). Therefore, changes in lymphocyte counts were calculated from blood smears collected before and approximately 2 weeks after the start of hormone treatment.

\section{METHODS}

\section{Study area and subjects}

This study was conducted on $P$. parvicornis males in inter-tidal pools (maximum depth $0.75 \mathrm{~m}$ ) 
on a flat basaltic inter-tidal platform at Feteira on the south coast of Faial Island, Azores ( $38^{\circ} 31^{\prime} \mathrm{N}$; $28^{\circ} 27^{\prime} \mathrm{W}$ ) during the breeding season (June-July) of 2004 .

One hundred and four individuals were captured with a hand net during low tide. At the end of the sampling procedure (see below), all subjects were individually tagged with plastic beads inserted at the base of the dorsal fin (as in Oliveira et al., 2001a) and were returned to the place of capture. Males returned to normal activities (foraging, nest defense, fanning) within minutes after releasing them. During low tide the pools were scanned for marked individuals.

The following measurements were taken: body mass (to the nearest $0.1 \mathrm{~g}$ ), standard length, the length and width of the genital papilla and the width of the first anal gland (to the nearest $0.1 \mathrm{~mm}$ ). Based on these measures, males were classified according to their morphotype: Mmorph (which includes two alternative behavioral tactics: sneakers and satellites: Santos, '85; Santos and Almada, '88; Oliveira et al., 2001b) as males with small genital papilla and undeveloped anal glands; $\mathrm{M}+$ morph (which include floaters and nest holders: Oliveira et al., 2001b) as males with large genital papilla and developed anal glands (Santos, '95). M- males that stayed in or around the territories of a single nest holder were classified as satellites. After capture, most of these males remained at the same territory but some of them were found roaming around in the pools. Although, M- males have been observed acting as satellites of several nest holders (Santos and Almada, '88), these males might have switched to a sneaker-like strategy after treatment (for doubts raised about these tactics, see Oliveira et al., 2001b).

\section{Experimental procedures and analyses of blood samples}

Immediately after catching, fish were anesthetized with a light dose of MS222 (tricaine methanesulfonate, Sigma-Aldrich; dilution 1:10,000) and blood was drawn from the caudal vein with a $1-\mathrm{ml}$ heparinized syringe fitted with a 25 -gauge needle. Blood was placed in 1-ml eppendorf tubes and kept on ice until further processing in the laboratory. This was done because occasionally weather conditions prevented us from processing blood samples in the field.

At first capture, males $(n=104)$ were randomly assigned to experimental groups. Thirty-three males served as control and received a silastic implant (length $=1 \mathrm{~cm}$, id $=1.47 \mathrm{~mm}$, od $=1.96 \mathrm{~mm}$ ) in the intra-peritoneal cavity containing $10 \mu \mathrm{l}$ castor oil (C group); 30 males received a silastic implant containing $20 \mu \mathrm{KT}$ dissolved in castor oil $(5 \mu \mathrm{g} \mathrm{KT} /$ $\mu \mathrm{l}$ castor oil; KT group); and 36 males received a silastic implant containing $20 \mu \mathrm{l} \mathrm{T}$ dissolved in castor oil $(5 \mu \mathrm{gT} / \mu \mathrm{l}$ castor oil; $\mathrm{T}$ group). All blood sampling and surgery was carried out at the field site and under anesthesia (MS222). Five animals did not wake up from anesthesia.

After returning to the laboratory (within 1-3 hr after taking the blood samples), a drop of blood was smeared over a slide and dried on air. Blood smears were stained for $20 \mathrm{~min}$ with Giemsa's azur eosin methylene blue solution (Merck KGaA, Germany) at 1:10 dilution with distilled water. Blood smears were evaluated under a microscope (BX-50, Olympus, Japan) at $100 \times$ magnification. For each subject twenty-five fields were counted from randomly chosen places on the smear and containing about 150 cells per field. The following cells were counted (see Ros et al., 2006): (1) granulocytes: large spherical cells of which the cytoplasm contains numerous fine granules; (2) lymphocytes: small spherical cells with little cytoplasm; (3) the total count of all cell types (erythrocytes and leukocytes) was estimated. This total count was used to calculate blood cell percentages of the leukocytes. The average within-subject coefficient of variation for these relative values was $4.1 \%$.

Similar hormonal implants as we used in this experiment have been shown to moderately elevate androgen levels for at least 1 week (for validation of KT implants see Ros et al., 2004; for validation of $\mathrm{T}$ implants see Modesto and Canário, 2003), and have been used previously to test hormonal effects on behavior and morphology in $P$. parvicornis (Oliveira et al., 2001d; Ros et al., 2004). In this experiment, we checked whether implants still affect levels of androgens 2 weeks after the start of the treatment. In order to do so, the free steroid fraction was extracted from $10 \mu \mathrm{l}$ plasma using the methodology described in Scott and Vermeirssen ('94). Steroid residues were re-suspended in $1 \mathrm{ml}$ assay buffer and stored again at $-20^{\circ} \mathrm{C}$ until assayed for $\mathrm{T}$ and $\mathrm{KT}$. The radioimmunoassays and cross-reactions for $\mathrm{T}$ and $\mathrm{KT}$ were described respectively in Scott et al. ('84) and Kime and Manning ('82). Intraassay and inter-assay precisions (coefficient of variation) were $7.4 \%$ and $12.4 \%$ for $\mathrm{T}$, and $8.2 \%$ and $11.6 \%$ for $\mathrm{KT}$. 


\section{Data analyses and statistics}

Twenty-four individuals were not re-captured within about 2 weeks after treatment (interval 11-15 days) and these were discarded from analyses, resulting in a final sample size of 75 individuals $(\mathrm{M}-\mathrm{C}=11, \mathrm{~T}=10, \mathrm{KT}=10 ; \mathrm{M}+$ : $\mathrm{C}=15, \mathrm{~T}=17, \mathrm{~T}=12$ ).

All statistical analyses were carried out with the SPSS 13.0 package (SPSS Inc., Chicago, USA) and $P$-values represent two-tailed probabilities. Measurements of anal gland length and androgen levels showed skewed distributions that were significantly deviating from normality (Kolgomorov-Smirnov, $P<0.01$ ). For statistical testing of these parameters, we used non-parametric statistics (e.g., Table 1). After transformation, distributions of the data for body measurements (using log transformation) and blood cell percentages of the leukocytes (using arcsin transformation) did not significantly deviate from normality (KolgomorovSmirnov, $P>0.10)$ and parametric statistics were carried out. In calculating two-way ANOVA statistics, the homogeneity assumption was violated for lymphocyte percentages but not for granulocyte percentages (levine's test, $P=0.014$, 0.14 , respectively). Descriptive analyses showed that four lymphocyte percentage values (3.46; $-3.24 ; 3.91 ; 9.32)$ were more than two box lengths from the edge of the box (range between quartiles: -0.43 and 0.72 for all data pooled). All these extremes were in the KT group. These values were discarded as outliers where after homogeneity was reached (levine's test, $P=0.4$ ). Deletion of these outliers did not change trends in the data (both positive and negative values only in KT group).

\section{RESULTS}

\section{Androgen levels}

Treatment was expected to increase androgen levels primarily in the first week after treatment.
Two weeks after the start of the treatment, levels of KT were still significantly increased in KT males in comparison to $\mathrm{T}$ and $\mathrm{C}$ males (Table 1 ). $\mathrm{T}$ levels did not significantly differ between groups. However, T-treated males had relatively high levels of $\mathrm{T}$ in comparison to total androgen levels $(\mathrm{T} /(\mathrm{T}+\mathrm{KT}) \%$ : Table 1$)$. This indicates that although androgen levels were not increased for the full 2-week periods, both treatments were successful in modulating androgen levels.

\section{Secondary sexual characters and swimming activity}

M- males treated with KT showed an increase in the size of the anal gland, while treatment with $\mathrm{T}$ did not induce anal gland growth (see Fig. 1a; Kruskal-Wallis Test: $\chi^{2}=16.2, \mathrm{DF}=2, P<0.001$ ). KT treatment decreased swimming activity to more than half of that of the control, while $\mathrm{T}$ treatment did not affect swimming activity (see Fig. 1b; Kruskal-Wallis Test: $\chi^{2}=6.2$, $\mathrm{DF}=2, P=0.040$ ). In $\mathrm{M}+$ males $\mathrm{KT}$ and $\mathrm{T}$ treatment had no significant effect on anal gland growth or swimming activity (Kruskal-Wallis Test: $\left.\chi^{2}<0.4, \mathrm{DF}=2, P>0.8\right)$. Qualitatively, $\mathrm{M}-$ males treated with KT showed to be site attached to a certain area in the tidal pool, while C- and T-treated males roamed around the pools. However, none of the $\mathrm{M}$ - males changed to nestholding behavior.

\section{Changes in leukocytes}

As expected, blood cell percentages of granulocytes did not correlate with total length or morphotype (average \pm SEM: $\mathrm{M}-(N=31): 0.067 \pm$ $0.017 \% ; \mathrm{M}+(N=44): 0.070 \pm 0.011 \%$; two-way ANCOVA: total length, $F(1,68)=0.44, P=0.51$; morphotype, $F(1,68)=1.39, P=0.24)$, while lymphocyte percentages were negatively correlated with total length and higher in $\mathrm{M}-$ than in $\mathrm{M}+$ males (average \pm SEM: $\mathrm{M}-(N=31): 2.7 \pm 1.8 \%$;

TABLE 1. Androgen plasma levels (KT=11-ketotestosterone, $T=$ testosterone) in blood samples of males of Parablennius parvicornis drawn 2 weeks after treatment (intra-peritoneal silastic implants)

\begin{tabular}{|c|c|c|c|c|c|c|c|c|c|}
\hline \multirow[b]{2}{*}{ Group } & \multicolumn{3}{|c|}{ KT levels } & \multicolumn{3}{|c|}{ T levels } & \multicolumn{3}{|c|}{$\mathrm{T} /(\mathrm{T}+\mathrm{KT}) 100$} \\
\hline & Median & Quartiles & $n$ & Median & Quartiles & $n$ & Median & Quartiles & $n$ \\
\hline $\mathrm{C}(\mathrm{ng} / \mathrm{ml})$ & 0.59 & $0.04-1.25$ & 20 & 0.39 & $0.20-1.48$ & 20 & 55.8 & $35.1-81.4$ & 14 \\
\hline $\mathrm{KT}(\mathrm{ng} / \mathrm{ml})$ & 1.84 & $0.24-3.42$ & 20 & 0.52 & $0.36-1.21$ & 20 & 25.6 & $20.6-58.2$ & 16 \\
\hline $\mathrm{T}(\mathrm{ng} / \mathrm{ml})$ & 0.04 & $0.04-0.59$ & 21 & 0.65 & $0.20-1.53$ & 21 & 89.7 & $52.6-96.7$ & 16 \\
\hline Kruskal-Wallis ANOVA & \multicolumn{3}{|c|}{$12.91 ; P=0.0016$} & \multicolumn{3}{|c|}{$1.01 ; P=0.60$} & \multicolumn{3}{|c|}{$19.01 ; P<0.0001$} \\
\hline Mann-Whitney $U$ test & \multicolumn{3}{|c|}{$\mathrm{KT}>\mathrm{T}, \mathrm{C}: P<0.05$} & \multicolumn{3}{|c|}{ N.S. } & \multicolumn{3}{|c|}{$\mathrm{T}>\mathrm{KT}, \mathrm{C}: P<0.05$} \\
\hline
\end{tabular}



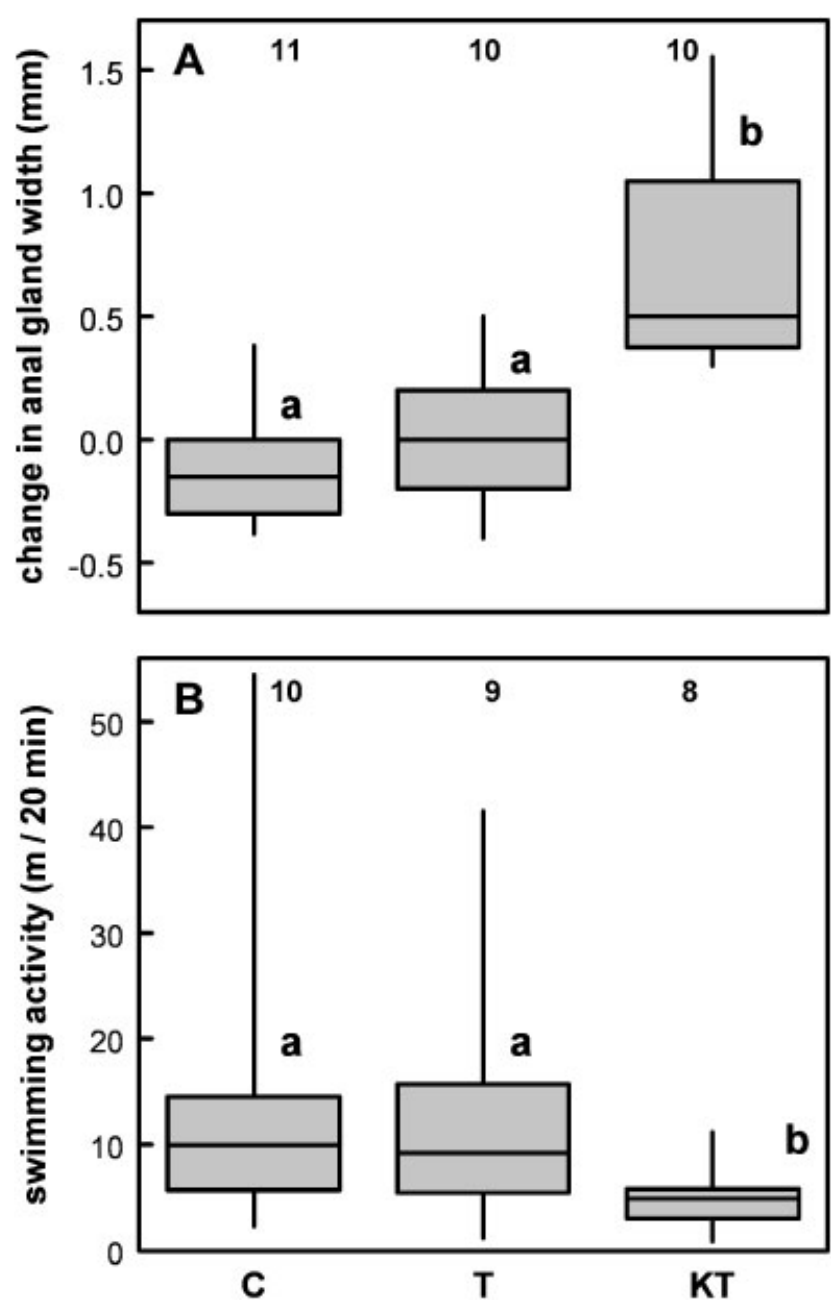

Fig. 1. Effect of androgen treatment $(\mathrm{C}=$ control, $\mathrm{KT}=11$-ketotestosterone, $\mathrm{T}=$ testosterone) on (A) the anal gland width and (B) the swimming activity of $\mathrm{M}-$ males of $P$. parvicornis. Numbers refer to $N$-values. Bars (median, quartiles and range) with different letters are significantly different at $P=0.05$.

$\mathrm{M}+(N=44): 1.0 \pm 0.7 \%$; two-way ANCOVA: total length, $\quad F(1,68)=33.5, \quad P<0.001 ;$ morphotype, $F(1,68)=19.7, P<0.001)$. Initial granulocyte and lymphocyte percentages were not significantly different with regard to subsequent hormone treatment (two-way ANCOVA: $F(2,68)<0.79$, $P>0.46$ ). Blood cell percentages of granulocytes did not change after androgen treatment $(F(2,69)=1.78, P=0.18)$. However, blood cell percentages of lymphocytes increased significantly after treatment in controls (Fig. 2; paired samples $T$-test: $T(25)=2.89, P=0.008)$. A two-way ANOVA showed a significant effect of treatment with change in lymphocyte percentages $(F(2,65)=3.82$, $P=0.027)$. Post hoc analyses showed that in comparison to the $\mathrm{C}$ group the blood cell percen-

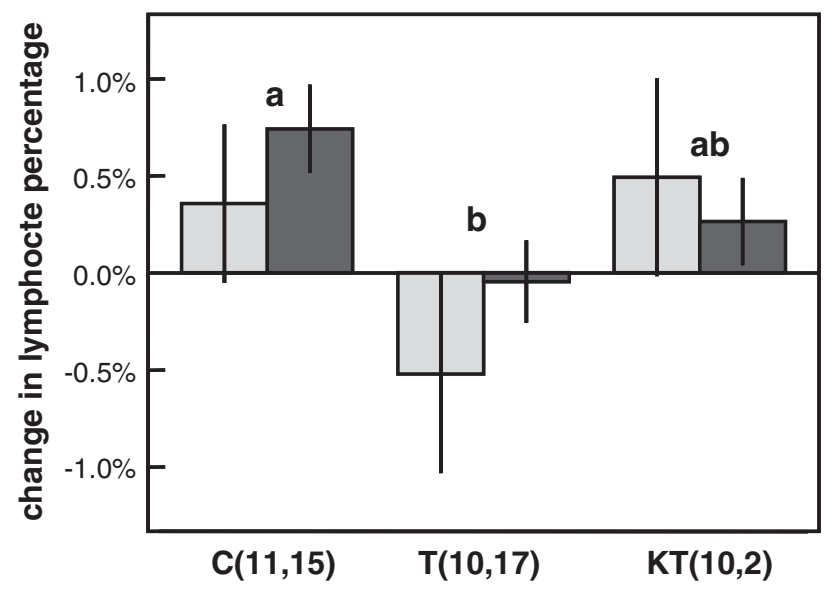

Fig. 2. Effect of androgen treatment $(\mathrm{C}=$ control, $\mathrm{KT}=11$-ketotestosterone, $\mathrm{T}=$ testosterone) on blood cell percentages of lymphocytes in $\mathrm{M}-$ (light gray bars) and $\mathrm{M}+$ (dark gray bars) males of $P$. parvicornis. Numbers between brackets refer to $N$-values. Bars (mean $\pm \mathrm{SE}$ ) with different letters are significantly different at $P=0.05$.

tages of lymphocytes decreased in the $\mathrm{T}$ group but not in the KT group (see Fig. 2). Changes in lymphocyte percentages did not differ between $\mathrm{M}-$ and $\mathrm{M}+$ males $(F(1,65)=1.98, P=0.16$; interaction with treatment: $F(2,65)=0.32, P=0.73)$.

\section{DISCUSSION}

In this study, we tested the immunocompetence handicap hypothesis in a blenny with polymorphism in the expression of secondary sexual characters associated with differences in androgen levels. As expected, treatment with $\mathrm{KT}$ induced the development of the anal gland, a secondary sexual character in $P$. parvicornis (Oliveira et al., 2001d). The anal gland grows as a modification of the first and second anal fin rays and has been found to produce pheromones in a related species (Laumen et al., '74; Zeeck and Ide, '96). Additionally, treatment with $\mathrm{KT}$ appeared to decrease swimming activity. This result suggests an increase in site fidelity in agreement with a switch in behavioral tactics from the $\mathrm{M}-$ to $\mathrm{M}+$ morph, or alternatively this decrease in activity might have been a consequence of increased energy expenditure for the production of the secondary sexual character. Treatment with $\mathrm{T}$ induced neither secondary sexual characters nor decreased swimming activity in $\mathrm{M}$ - males indicating that conversion of $\mathrm{T}$ to $\mathrm{KT}$ is necessary for the development of secondary sexual characters in the target tissues. In a previous study (Ros et al., 
2006), we reported that blood cell percentages of lymphocytes and antibody responsiveness were relatively lower in the morph expressing secondary sexual characters and having highest levels of androgens, but the correlative data did not suggest a causal relationship. This study shows that treatment with $\mathrm{T}$ suppressed blood cell percentages of lymphocytes but not granulocytes, while treatment with KT was not followed by significant changes in leukocytes. Summarizing, we found evidence suggesting KT to be the primary androgen promoting the switch from the $\mathrm{M}-$ to $\mathrm{M}+$ morph (for a discussion on this subject see: Oliveira et al., 2001b,d; Oliveira, 2005), while we found $\mathrm{T}$ to have an effect on immunity.

Androgen treatment was given in the form of silastic implants that are known to elevate androgen levels for at least 1 week and that have behavioral effects for at least 2 weeks (Oliveira et al., 2001d; Modesto and Canário, 2003; Ros et al., 2004). In this study, measured about 2 weeks after treatment, we found increased levels of KT in the $\mathrm{KT}$ group, and relatively high T levels in comparison to $\mathrm{KT}$ levels in the T group. The latter might have been produced by a change in enzyme levels that metabolize endogenous androgens (reviewed in Knapp, 2003). High T in comparison to KT has been found to correlate negatively with territorial behavior (e.g., Oliveira, 2004), while increased KT levels facilitate territorial behavior in $P$. parvicornis (Ros et al., 2004). This suggest that within 2 weeks most androgen was diffused from the implants but that the treatment had still moderate effect on the endogenous production of androgens.

Sexual traits have been suggested to be costly not only due to a depletion of metabolic resources necessary for their expression but also based on the observation that androgens whose levels are elevated during secondary sexual characters production, were found to be correlated with immunosuppression (Folstad and Karter, '92; Kotiaho, 2001). This cost of elevated levels of androgens postulated in the immunocompetence handicap hypothesis (Folstad and Karter, '92) has been tested during the last decade in a wide variety of species. In mammals, a group with elevated competition for sexual resources and strong sex-linked differences in reproductive behavior and androgen production, differences in testosterone levels (including differences between sexes) co-vary with parasite infestation and changes in immune function according to the predictions of this hypothesis (reviewed in Klein, 2004).
However in avian species, which in comparison to mammals are more variable in their relationship between secondary sexual characters, hormones and gender (Sheldon and Verhulst, '96; Kimball and Ligon, '99; Eens and Pinxten, 2000; Ball and Balthazart, 2004), treatment with androgens did not consistently suppress cellular or humoral immunocompetence (Nava et al., 2001; Roberts et al., 2004). The apparent increase in parasite load found in birds after androgen treatment, may be related to changes in behavior mediated by the testosterone treatment that resulted in greater exposure to the parasites (Saino and Møller, '94; Roberts et al., 2004). Teleost fish have been studied to a far lesser extend (for a recent review see Yada and Nakanishi, 2002), despite the fact that they offer a wide variation in mating systems, thereby being a good model for the study of the evolution of hormone-related mechanisms.

In this study, we estimated the effects of hormonal treatment on humoral immunity by using a monitoring method, i.e., counting lymphocytes before and after treatment (discussed in Norris and Evans, 2000; Nava et al., 2001). We chose this method because in an earlier study (Ros et al., 2006) we found lower blood cell percentages of lymphocytes (not granulocytes) in the $\mathrm{M}+$ morphotype than in the $\mathrm{M}$ - morphotype, a result confirmed in this study. Furthermore, the differences between the morphotypes were associated with differences in the antibody response to immunization with sheep red blood cells, indicating differences in immunocompetence rather than in the status of infection. Interestingly, the effect of $\mathrm{T}$ on lymphocyte percentages compared to the levels of controls (about 1\% lower, which translates to about $40 \%$ less lymphocytes in the blood), was in the order of the difference between morphotypes (1-1.5\% higher in $\mathrm{M}+$ than in $\mathrm{M}-$ males, this study; Ros et al., 2006). This suggests that long-lasting exposure to elevated $\mathrm{T}$ levels lowers blood cell percentages of lymphocytes in $P$. parvicornis. We did not find such significant suppression of lymphocytes by KT. Lymphocyte but not granulocyte percentages increased in control and KT-treated fish, indicating a slight trauma due to the operation procedure.

A decrease in lymphocytes might have been a result of immunoredistribution or immunosuppression. Leukocytes including lymphocytes have been shown to migrate from the bloodstream to lymphoid tissues and to the skin as a consequence of temporary stress, and this trafficking of leukocytes has been proposed to be an adaptive stress 
response because it reinforces the primary protection to invading pathogens in the context of a dangerous situation (Dhabhar, 2002). Trafficking can be blocked by administering a type II adrenal steroid receptor antagonist and induced by injection with corticosteroids, and plasma levels of leukocytes are restored to baseline after cessation of the stressor (see Dhabhar, 2002). Braude et al. ('99) proposed that androgens might act via similar mechanisms leading to leukocyte trafficking. To our knowledge it has not been studied yet whether this might occur due to variation in endogenous androgen levels as a response to aggressive challenges, and independent from adrenal hormones. Furthermore, in analogy with the effects of corticosteroids, one might expect that temporal variation in androgen would be correlated with such redistribution, but that more chronic changes in the androgen levels in the end would result in immunosuppression (see Dhabhar, 2002; Yada and Nakanishi, 2002). Moreover, treatment of teleost leukocytes in vitro suggest a causal mechanism for immunosuppression by androgens (Slater and Schreck, '93; Yamaguchi et al., 2001; Saha et al., 2004). Thus although immunoredistribution is possible, immunosuppression remains the most likely explanation for the relatively low blood cell percentages of lymphocytes in T-treated males in this experiment.

The regulation by different androgens we found in our experiment, could be in concert with the immunocompetence handicap hypothesis in case $\mathrm{T}$ and $\mathrm{KT}$ would covariate. However, circulating levels of $\mathrm{KT}$ and $\mathrm{T}$ are not necessarily correlated due to modulation of the activity of the enzymes $11 \beta$-hydroxylase and $11 \beta$-hydroxysteroid dehydrogenase that metabolize T to KT (Knapp, 2003; Oliveira, 2005). This metabolization of $\mathrm{T}$ may take place in the gonads, red blood cells and/or the liver (Mayer et al., '90; Borg, '94; Cavaco et al., '97) and may allow males to modulate immunocompetence independently from androgen-dependent sexual traits since the expression of secondary sexual character is KT dependent (Oliveira, 2005). In a comparable way, males might decouple central effects of testosterone from peripheral effects of the hormone by modulating the amount of aromatization in the brain (Schlinger et al., '99; Forlano et al., 2001). Moreover, cortisol, progesterone and estrogen exert their own reproductionrelated effects on immunity (reviewed by Harris and Bird, 2000; Yada and Nakanishi, 2002). This leads to many degrees of freedom in the inter- action between male sexual traits and immunocompetence and this complexity should be considered when reviewing the androgen modulation of trade-offs proposed by the Immunocompetence Handicap Hypothesis (see Wedekind and Folstad, '94; Casto et al., 2001). More than a decade of studies after the immunocompetence handicap hypothesis was initially postulated, it is tentative to propose that in some species androgen-dependent effects on immunity and on secondary sexual characters may be compartmentalized so that pleiotropic-like effects are not or no longer present. This might break the proposed androgen-regulated trade-off in these species.

\section{ACKNOWLEDGMENTS}

We are very grateful to Tânia Oliveira for running the radioimmunoassay and Rick Bruintjes for his help during the fieldwork. We also thank two anonymous referees for their efforts to improve the manuscript. During this study, A.F.H.R. was being supported by a postdoctoral fellowship from the Portuguese Foundation for Science and Technology (FCT) (SFRH/ BPD/7143/2001). The research is additionally supported by FCT's Plurianual Program to R\&D Unit 331/94 and R\&D Unit 531/96. The procedures used in this study meet the ABS/ASAB ethical guidelines, and comply with the current laws of Portugal.

\section{LITERATURE CITED}

Ball GF, Balthazart J. 2004. Hormonal regulation of brain circuits mediating male sexual behavior in birds. Physiol Behav 83:329-346.

Borg B. 1994. Androgens in teleost fishes. Comp Biochem Physiol C: Toxicol Pharmacol 109:219-245.

Braude S, Tang-Martinez Z, Taylor GT. 1999. Stress, testosterone, and the immunoredistribution hypothesis. Behav Ecol 10:345-350.

Campbell B, Dickey JT, Swanson P. 2003. Endocrine changes during onset of puberty in male spring Chinook salmon, Oncorhynchus tshawytscha. Biol Reprod 69:2109-2117.

Casto JM, Nolan V Jr, Ketterson ED. 2001. Steroid hormones and immune function: experimental studies in wild and captive dark-eyed juncos (Junco hyemalis). Am Nat 157: 408-420.

Cavaco JEB, Vischer HF, Lambert JGD, Goos HJT, Schulz RW. 1997. Mismatch between patterns of circulating and testicular androgens in African catfish, Clarias gariepinus. Fish Physiol Biochem 17:155-162.

Cichoñ M, Dubiec A, Chadziñska M. 2001. The effect of elevated reproductive effort on humoral immune function in collared flycatcher females. Acta Oecol 22:71-76.

Deerenberg C, Apanius V, Daan S, Bos N. 1997. Reproductive effort decreases antibody responsiveness. Proc R Soc Lond B: Biol Sci 264:1021-1029. 
Demas GE. 2004. The energetics of immunity: a neuroendocrine link between energy balance and immune function. Horm Behav 45:173-180.

Dhabhar FS. 2002. Stress-induced augmentation of immune function-the role of stress hormones, leukocyte trafficking, and cytokines. Brain Behav Immun 16:785-798.

Eens M, Pinxten R. 2000. Sex-role reversal in vertebrates: behavioural and endocrinological accounts. Behav Process 51:135-147.

Folstad I, Karter AJ. 1992. Parasites, bright males, and the immunocompetence handicap. Am Nat 139:603-622.

Forlano PM, Deitcher DL, Myers DA, Bass AH. 2001. Anatomical distribution and cellular basis for high levels of aromatase activity in the brain of teleost fish: aromatase enzyme and mRNA expression identify glia as source. J Neurosci 21:8943-8955.

Harris J, Bird DJ. 2000. Modulation of the fish immune system by hormones. Vet Immunol Immunopathol 77: 163-176.

Hou YY, Suzuki Y, Aida K. 1999. Effects of steroid hormones on immunoglobulin $\mathrm{M}$ (IgM) in rainbow trout, Oncorhynchus mykiss. Fish Physiol Biochem 20:155-162.

Kimball RT, Ligon JD. 1999. Evolution of avian plumage dichromatism from a proximate perspective. Am Nat 154: 182-193.

Kime DE, Manning NJ. 1982. Seasonal patterns of free and conjugated androgens in the brown trout Salmo trutta. Gen Comp Endocrinol 48:222-231.

Kindler PM, Bahr JM, Philipp DP. 1991. The effects of exogenous 11-ketotestosterone, testosterone, and cyproterone acetate on prespawning and parental care behaviors of male bluegill. Horm Behav 25:410-423.

Klein SL. 2004. Hormonal and immunological mechanisms mediating sex differences in parasite infection. Parasite Immunol 26:247-264.

Knapp R. 2003. Endocrine mediation of vertebrate male alternative reproductive tactics: the next generation of studies. Integr Comp Biol 43:658-668.

Kotiaho JS. 2001. Costs of sexual traits: a mismatch between theoretical considerations and empirical evidence. Biol Rev Camb Philos Soc 76:365-376.

Laumen J, Pern U, Blüm V. 1974. Investigations on the function and hormonal regulations of the anal appendices in Blennius pavo. J Exp Zool 190:47-56.

Law WY, Chen WH, Song YL, Dufour S, Chang CF. 2001. Differential in vitro suppressive effects of steroids on leukocyte phagocytosis in two teleosts, tilapia and common carp. Gen Comp Endocrinol 121:163-172.

Manning NJ, Kime DE. 1985. The effect of temperature on testicular steroid production in the rainbow trout, Salmo gairdneri, in vivo and in vitro. Gen Comp Endocrinol 57: 377-382

Mayer I, Borg B, Schulz R. 1990. Conversion of 11-ketoandrostenedione to 11-ketotestosterone by blood cells of six fish species. Gen Comp Endocrinol 77:70-74.

Miranda JA, Oliveira RF, Carneiro LA, Santos RS, Grober MS. 2003. Neurochemical correlates of male polymorphism and alternative reproductive tactics in the Azorean rock- pool blenny, Parablennius parvicornis. Gen Comp Endocrinol 132:183-189.

Modesto T, Canário AV. 2003. Hormonal control of swimbladder sonic muscle dimorphism in the Lusitanian toadfish Halobatrachus didactylus. J Exp Biol 206: 3467-3477.
Nava MP, Veiga JP, Puerta M. 2001. White blood cell counts in house sparrows (Passer domesticus) before and after moult and after testosterone treatment. Can J Zool/Rev Can Zool 79:145-148.

Norris K, Evans MR. 2000. Ecological immunology: life history trade-offs and immune defense in birds. Behav Ecol 11: $19-26$.

Oliveira RF. 2004. Social modulation of androgens in vertebrates: mechanisms and function. Adv Study Behav 34:165-239.

Oliveira RF. 2005. Neuroendocrine mechanisms of alternative reproductive tactics in fish. In: Sloman KA, Wilson RW, Balshine S, editors. Behaviour and physiology of fish; Hoar WS, Randall DJ, Farrell AP, series editors. Behaviour: interactions with physiology, Vol. 24. New York: Elsevier. p 297-357.

Oliveira RF, Almada VC, Gonçalves EJ, Forsgren E, Canário AVM. 2001a. Androgen levels and social interactions in breeding males of the peacock blenny. J Fish Biol 58: 897-908.

Oliveira RF, Canário AV, Grober MS. 2001b. Male sexual polymorphism, alternative reproductive tactics, and androgens in combtooth blennies (pisces: blenniidae). Horm Behav 40:266-275.

Oliveira RF, Canário AV, Grober MS, Santos RS. 2001c. Endocrine correlates of male polymorphism and alternative reproductive tactics in the Azorean rock-pool blenny, Parablennius sanguinolentus parvicornis. Gen Comp Endocrinol 121:278-288.

Oliveira RF, Carneiro LA, Canário AV, Grober MS. 2001d. Effects of androgens on social behavior and morphology of alternative reproductive males of the Azorean rock-pool blenny. Horm Behav 39:157-166.

Peters A. 2000. Testosterone treatment is immunosuppressive in superb fairy-wrens, yet free-living males with high testosterone are more immunocompetent. Proc R Soc Lond B Biol Sci 267:883-889.

Roberts ML, Buchanan KL, Evans MR. 2004. Testing the immunocompetence handicap hypothesis: a review of the evidence. Anim Behav 68:227-239.

Robertson OH. 1961. Prolongation of the life span of kokanee salmon (Oncorhynchus nerka kennerlyi) by castration before beginning of gonad development. Proc Natl Acad Sci USA 47:609-621.

Ros AFH, Bruintjes R, Santos RS, Canário AVM, Oliveira RF. 2004. The role of androgens in the trade-off between territorial and parental behavior in the Azorean rockpool blenny, Parablennius parvicornis. Horm Behav 46: 491-497.

Ros AFH, Bouton N, Santos RS, Oliveira RF. 2006. Alternative male reproductive tactics and the immunocompetence handicap in the Azorean rock pool blenny, Parablennius parvicornis. Proc R Soc Lond B Biol Sci 273:901-909.

Saha NR, Usami T, Suzuki Y. 2003. A double staining flow cytometric assay for the detection of steroid induced apoptotic leucocytes in common carp (Cyprinus carpio). Dev Comp Immunol 27:351-363.

Saha NR, Usami T, Suzuki Y. 2004. In vitro effects of steroid hormones on IgM-secreting cells and IgM secretion in common carp (Cyprinus carpio). Fish Shellfish Immunol 17: 149-158.

Saino N, Møller AP. 1994. Secondary sexual characters, parasites and testosterone in the barn swallow, Hirundo rustica. Anim Behav 48:1325-1333. 
Santos RS. 1985. Parentais e satélites: Tácticas alternativas de acasalamento nos machos de Blennius sanguinolentus Pallas (Pisces: Blenniidae). Arquipel 6:119-146.

Santos RS. 1989. Observações sobre os intervalos de desenvolvimento de Parablennius sanguinolentus (Pallas) (Pisces: Blenniidae) dos Açores: Períodos embrionário, larvar e juvenil. Arq Mus Bocage 1:293-310.

Santos RS. 1995. Anatomy and histology of secondary sexual characters, gonads and liver of the rock-pool blenny (Parablennius sanguinolentus parvicornis) of the Azores. Arquipel 13:21-38.

Santos RS, Almada VC. 1988. Intraspecific variations in reproductive tactics in males of the rocky intertidal fish Blennius sanguinolentus in the Azores. In: Chelazzi G, Vannini M, editors. Behavioral adaptation to intertidal life. NATO Advanced Research Workshop on Behavioral Adaptation to Intertidal Life, Castiglioncello, Italy, May 19-24, 1987. New York: Plenum Publishing Corporation. p 421-447.

Schlinger BA, Greco C, Bass AH. 1999. Aromatase activity in the hindbrain vocal control region of a teleost fish: divergence among males with alternative reproductive tactics. Proc R Soc Lond B: Biol Sci 266:131-136.

Schmid-Hempel P. 2003. Variation in immune defence as a question of evolutionary ecology. Proc R Soc Lond B: Biol Sci 270:357-366.

Scott AP, Vermeirssen ELM. 1994. Production of conjugated steroids by teleost gonads and their role as pheromones. In: Davey KG, Peter RE, Tobe SS, editors. Perspectives in comparative endocrinology. Ottawa: National Research Council of Canada. p 645-654.

Scott AP, MacKenzie DS, Stacey NE. 1984. Endocrine changes during natural spawning in the white sucker, Catostomus commersoni. II. Steroid hormones. Gen Comp Endocrinol 56:349-359.

Sheldon BC, Verhulst S. 1996. Ecological immunology: costly parasite defences and trade-offs in evolutionary ecology. Trends Ecol Evol 11:317-321.

Slater CH, Schreck CB. 1993. Testosterone alters the immune response of chinook salmon, Oncorhynchus tshawytscha. Gen Comp Endocrinol 89:291-298.
Slater CH, Schreck CB. 1997. Physiological levels of testosterone kill salmonid leukocytes in vitro. Gen Comp Endocrinol 106:113-119.

Slater CH, Schreck CB. 1998. Season and physiological parameters modulate salmonid leucocyte androgen receptor affinity and abundance. Fish Shellfish Immunol 8: 379-391.

Slater CH, Fitzpatrick MS, Schreck CB. 1995a. Androgens and immunocompetence in salmonids: specific binding in and reduced immunocompetence of lymphocytes exposed to natural and synthetic androgens. Aquaculture 136: 363-370.

Slater CH, Fitzpatrick MS, Schreck CB. 1995b. Characterization of an androgen receptor in salmonid lymphocytes: possible link to androgen-induced immunosuppression. Gen Comp Endocrinol 100:218-225.

Watanuki H, Yamaguchi T, Sakai M. 2002. Suppression in function of phagocytic cells in common carp Cyprinus carpio L. injected with estradiol, progesterone or 11-ketotestosterone. Comp Biochem Physiol C: Toxicol Pharmacol 132: 407-413.

Wedekind C, Folstad I. 1994. Adaptive or nonadaptive immunosuppression by sex hormones? Am Nat 143:936-938.

Witten PE, Hall BK. 2002. Differentiation and growth of kype skeletal tissues in anadromous male Atlantic salmon (Salmo salar). Int J Dev Biol 46:719-730.

Yada T, Nakanishi T. 2002. Interaction between endocrine and immune systems in fish. Int Rev Cytol 220:35-92.

Yamaguchi T, Watanuki H, Sakai M. 2001. Effects of estradiol, progesterone and testosterone on the function of carp, Cyprinus carpio, phagocytes in vitro. Comp Biochem Physiol C: Toxicol Pharmacol 129:49-55.

Zander CD. 1979. Morphologische und Ökologische Untersuchung der Schleimfische Parablennius sanguinolentus (Pallas, 1811) und $P$. parvicornis (Valenciennes, 1836) (Perciformes, Blenniidae). Mitteilungen 76:469-474.

Zeeck E, Ide V. 1996. The role of sex pheromones in the reproductive behaviour of Blennius pavo (Risso). In: Canário AVM, Power D, editors. Fish pheromones: origins and mode of action. Faro: University of Algarve. p 33-38. 